\title{
Nutrients retention in a small subtropical wetland (México)
}

\author{
Martha B. RENDÓN-LÓPEZ, ${ }^{*}$ M. Luisa SUAREZ ALONSO,${ }^{2}$ Gloria L. AYALA-RAMIREZ,, Yazmin HERNÁNDEZ- \\ LINARES, ${ }^{1}$ Alberto GÓMEZ-TAGLE CHAVEZ, ${ }^{1}$ Julio C. MEDINA-AVILA, ${ }^{1}$ M. Rosario VIDAL-ABARCA ${ }^{2}$ \\ ${ }^{1}$ Institute of Research of Natural Resources, University Michoacana of San Nicolas de Hidalgo, San Juanito Itzicuaro S/N, Col. Nueva \\ Esperanza, C.P. 58337 Morelia, Michoacán, México; ${ }^{2}$ Department of Ecology and Hydrology, Regional Campus of International \\ Excellence "Campus Mare Nostrum”, University of Murcia, Campus de Espinardo, 30100 Murcia, Spain \\ *Corresponding author: mbeatrizrl@hotmail.com
}

\begin{abstract}
In tropical areas very few studies have analyzed wetlands'ability to control nutrients. We analyzed the efficiency of the Pátzcuaro subtropical wetland in Mexico to retain nutrients (total phosphorus: TP; soluble reactive phosphorus: $\mathrm{PO}_{4}{ }^{3-}$, nitrite: $\mathrm{NO}_{2}^{-}$and nitrate: $\mathrm{NO}_{3}^{-}$) and total suspended solids (TSS) and its temporal variability from November 2011 to October 2012, where two hydrological different periods (dry and wet periods) were included. The results indicate that, annually, this wetland reduced $\mathrm{TP}, 30.4 \%$; $\mathrm{PO}_{4}^{3-}, 19.2 \%$; $\mathrm{NO}_{2}^{-}, 2.5 \% ; \mathrm{NO}_{3}^{-}, 17.6 \%$; and TSS, $14.7 \%$. However, the reduction \% rose to $55.3 \%$ for TP and to $47.3 \%$ for $\mathrm{PO}_{4}{ }^{3-}$ during the dry period and to $14.1 \%$ for $\mathrm{NO}_{2}^{-}, 49 \%$ for $\mathrm{NO}_{3}^{-}$and $44.5 \%$ for TSS during the rainy period. These results show dependence on the hydrological cycle, although P retention is also related with uptake by a dense macrophyte community and with organic matter accumulation. The results obtained suggest that removal of $N$ is due mainly to denitrification. TSS retention seems to respond to low speed hydraulics and the resistance generated by macrophytes roots and floating plants. Like other studies in temperate environments, this wetland seems to remove more efficiently $P$ than $N$. Unlike that in temperate environments where the highest nutrient retention occurs in autumn, we found the highest retention values for both $\mathrm{NO}_{2}^{-}$and $\mathrm{NO}_{3}^{-}$during summer (rainy period), and the lowest for P, probably due to release of $P$ for the senescence of wetland plants during this period.
\end{abstract}

Key words: Nitrates; phosphates; total phosphorus; organic matter; hydrological periods; Pátzcuaro wetland.

Received: March 2015. Accepted: September 2015

\section{INTRODUCTION}

Wetlands are recognized as one of the world's most productive ecosystems (Costanza et al., 1997). Their ability to provide ecosystem services, such as supply (e.g., food, water, raw materials, etc.), regulation (e.g., carbon storage, control of erosion, natural disturbances, etc.) and cultural (e.g., recreational activities, environmental education) has been internationally acknowledged (Millennium Ecosystem Assessment, 2005; Zak et al., 2011; McInnes, 2013). Among these services, emphasis is placed on high self-purification capacity to control nutrient and sediment dynamics, minimise eutrophication effects and contribution to water quality maintenance (Johnston, 1991). In fact, wetlands are recognised for their ability to retain, transform and assimilate nutrients (Mitsch, 1992; Woltemade, 2000; Hoffmann et al., 2009), although the mechanisms by which nutrients and organic matter are retained are still not fully understood (Fisher and Acreman, 2004).

Nutrients like nitrogen and phosphorus are essential for plant growth, but excessive concentrations can trigger algae blooms, limiting light penetration, and lower the dissolved oxygen concentration, which eventually develop into surface waters (rivers, lakes, reservoirs) eu- trophication (Vitousek et al., 1997; Smith, 2003). Therefore, retention of nitrogen and phosphorus in wetlands can benefit the water bodies associated with them by improving the quality of the water (Johnston, 1991; Fisher and Acreman, 2004). Excessive nutrients discharges, from both point sources (e.g., direct discharges and industrial organic) and diffuse sources through runoff from agricultural lands, have been accepted as one of the most important causes of pollution problems and aquatic ecosystem eutrophication in the world (Conley et al., 2009; GarcíaGarcía et al., 2013; Kopacek et al., 2013). Several studies have shown that small wetlands can act as sinks for nutrients by controlling non-point sources of pollution in agricultural areas, and have demonstrated their natural potential to control water quality (Knox et al., 2008; García-García et al., 2009, 2013). However, their retention capacity depends on the type of nutrients that arrive at the wetland. Different studies have revealed that the majority of the wetlands that reduce nutrients discharge present different percentages of nitrogen and phosphorus reduction rates (Johnston, 1991). Nitrogen is easily removed via denitrification under anaerobic conditions, besides biological uptake and microbial immobilization (Vymazal, 2007). Yet there is evidence that wetlands are less efficient at retaining soluble phosphorus (Hoffman et al., 2012) 
and in wetlands dominated by surface water flow, such as Pátzcuaro wetland, is controlled by physical, geochemical and biological processes (Sabater et al., 2003; Hoffman et al., 2009). In addition, this retention can be affected by the hydrological cycle phase (AlMaarofi et al., 2013). Broadly, reduced nutrients retention from wetlands occurs frequently in autumn in temperate areas to coincide with the periods of highest precipitation and increased water flows (Fisher and Acreman, 2004). Nitrogen retention efficiency tended to increase during summer months due mainly biological uptake and denitrification (Garcia-Garcia et al., 2009). In relation to phosphorus, Reddy et al. (2010) suggest that during dry period retention of phosphorus depending to abiotic characteristics of sediment wetland. So, four processes can be involved in phosphorus retention: adsorption to the exchangeable complex; precipitation joined to $\mathrm{Ca}, \mathrm{Mg}$ or carbonates; adsorption to Fe oxides and absorption to aquatic plants (Alvarez-Rogel et al., 2006).

In general, information available on natural tropical wetlands is very fragmented and has been developed fundamentally from descriptive approaches (e.g., physicochemical characterization, floristic and faunistic inventories, and human impacts) (Junk, 2002). Very few studies have analyzed functional aspects such as wetlands' ability to control nutrients. On the contrary, the few studies that actually exist have been conducted mostly in artificial wetlands (Vymazal, 2007). Despite the important ecoservices that wetlands generally provide to the human population, tropical and subtropical wetlands are increasingly threatened because of higher population density, increasing demand for water and land, and also because many are relatively small (Junk, 2002). In Mexico, around $62.1 \%$ of wetlands, including brackish, marine and freshwater wetlands, have been lost (Landgrave and MorenoCasasola, 2012) despite the existing legal framework to promote wetland conservation and sustainable use (Morzaria-Luna et al., 2014).

The subtropical Lake Pátzcuaro wetland, declared a RAMSAR site in 2005 (No. 1447), is considered a buffer zone that receives significant runoff, which contributes to maintain the water level and the water and biological quality of Lake Pátzcuaro (Chacón-Torres and MúzquizIribe, 1997). This wetland supports the local economy of many indigenous populations, such as raw material (vegetation) for craft activities, besides tourism, fishing and forestry (Chacón-Torres, 1993; Bernal-Brooks, 2002; García-Villanueva, 2007). Recently, progressive wetland deterioration has been detected by the pressure that anthropogenic activities in the region cause (mainly deforestation, land-use change to agriculture, livestock rearing, and organic effluents) (Bravo-Inclán et al., 2012). Yet despite the importance of this wetland for maintaining its water quality, there are no studies that quantify its poten- tial for retaining nutrient. So, the main objectives of this study are to: i) quantify retention capacity for the nutrients (nitrates, $\mathrm{NO}_{3}^{-}$; nitrites, $\mathrm{NO}_{2}^{-}$; soluble reactive phosphorus, $\mathrm{PO}_{4}^{3-}$; total phosphorous) of the South Lake Pátzcuaro wetland over an annual cycle; ii) analyze the effects of temporal hydrological variability on nutrients retention; iii) examine the effect of environmental factors on nutrients retention.

\section{METHODS}

\section{Study area}

This study was carried out in a subtropical wetland located in the Mexican State of Michoacán within the Mexican transvolcanic Belt in the Lake Pátzcuaro-Cuitzeo basin, where Lake Pátzcuaro watershed is located. This wetland covers 707 hectares and lies between UTM coordinates $X=246175.12,204562.47$ (East longitude), and $\mathrm{Y}=2171501.92,2145020.65$ (North latitude) at an altitude of $2036 \mathrm{~m}$ asl (Fig. 1). This wetland is associated with the south Lake Pátzcuaro (13,000 hectares), and is surrounded by a series of hills and volcanoes following an altitudinal profile in a southern direction. The wetland is located in the foothills of La Taza volcano (2339 m asl), a geological unit dominated by malpais, and a vast valley of agricultural land, in which the former island of Jarácuaro was formed by lake sediments (Garduño-Monroy et al., 2009). The slope of the basin is abrupt and at a short distance to the wetland, with a plain whose slopes are less than $3 \%$, and hills of volcanic material that favor surface runoff and carry solid materials, which cause siltation and the shallowness of the wetland (Bischoff et al., 2004). The climate is temperate humid with summer rains and less than $5 \mathrm{~mm}$ of winter rainfall (INEGI, 2008a). The wetland is crossed by a series of artificial navigation channels, used by the human communities around the lake. It should be emphasized that there are no permanent streams in the study area (Fig. 1). Therefore, any water flow to the wetland is produced basically by runoff (INEGI, 2008b) and probably by shallow ground-water flows, which occur primarily in the summer rainy season (Bischoff et al., 2004). The wetland is shallow, its maximum depth does not exceed $150 \mathrm{~cm}$, and the water velocity is practically zero $\left(0.05 \mathrm{~cm} \mathrm{~s}^{-1}\right)$ (Ayala et al., 2008). However the wetland does not dry and a shallow layer of water remains during the dry season. The soils near the wetland have a sandy and loamy texture. They are easily erodible and slightly acidic, and are associated with the volcanic origin of the region, represented mainly by andosols and luvisols (Vargas et al., 2000; Bravo-Espinoza et al., 2006). We have not detected peat in the wetland. About $19 \%$ of the wetland is used to agriculture and almost $46 \%$ is occupied by the Jarácuaro Island where some villages exist. Surrounding wetland there are wooded pine oak areas (Huerto-Delgadillo and García, 2011). Besides livestock is 
an important activity in the wetland. To the south of Lake Pátzcuaro, a progressive silting process is underway, caused by deforestation and inappropriate agricultural practices, including use of agrochemicals (Rojas, 2002), which give rise to the input of contaminants from such activities, and the wastewater from nearby villages also contribute (Vargas et al., 2000). A diverse and dense macrophytes community covers the wetland including emerging macrophytes (Thy-

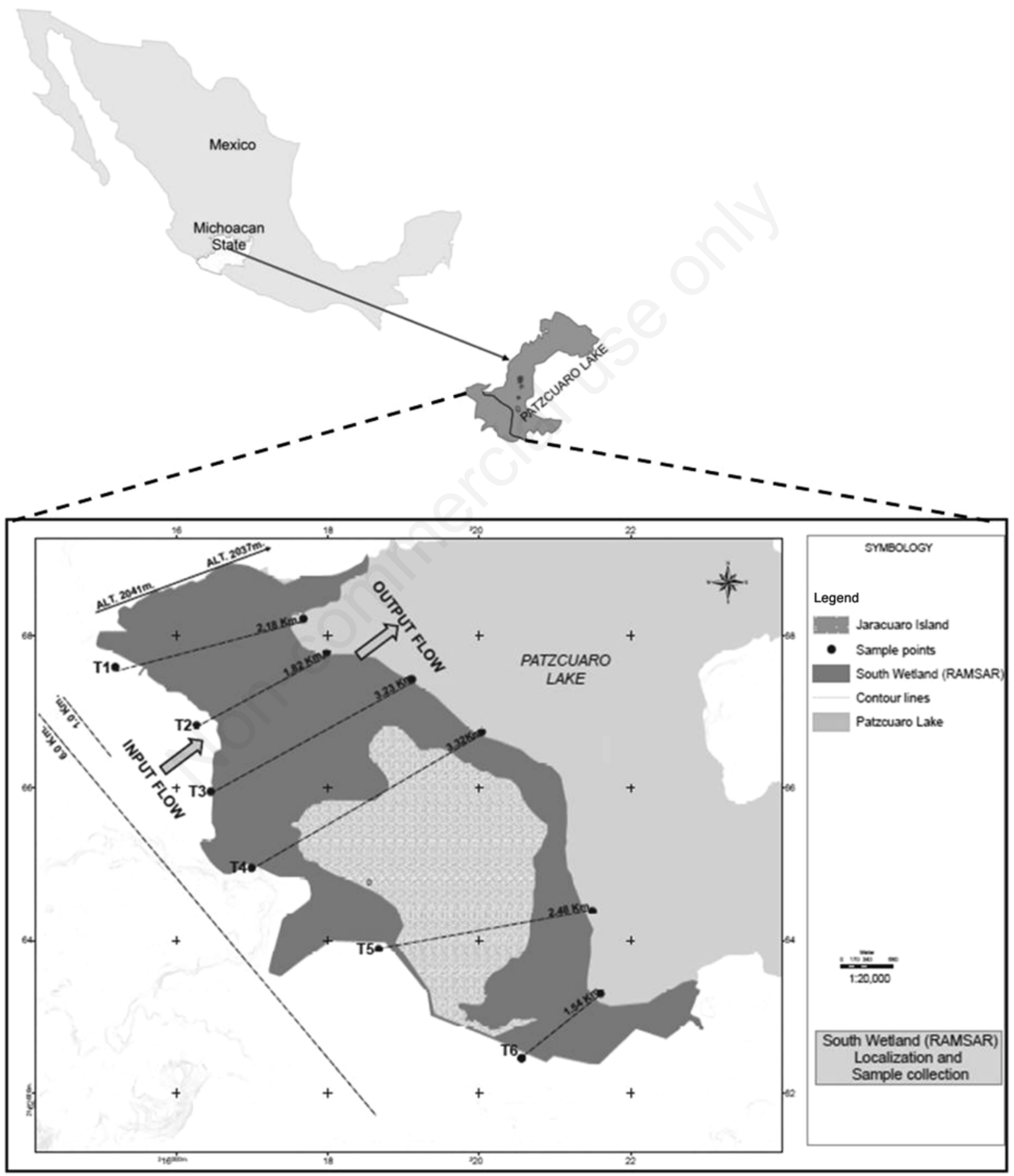

Fig. 1. Location of the South Lake Pátzcuaro wetland and sampling points. T1, T2, T3, T4, T5 and T6 represent the transects where samples were collected. 
pha dominguensis, Schoenoplectus californicus and Phragmites australis), floating leaves (Nymphaea mexicana), and submerged (Potamogeton illinoesis and P. pectinatus) and free floating (Eichhornia crassipes and Oxycarium cubense) (Bernal-Brooks et al., 2003). The practice of burning and conditioning the land for agricultural use is commonplace in the wetland (Huerto-Delgadillo and García, 2011).

Although there are no previous physico-chemical characteristics data of the water in the wetland, some studies indicate that the waters of the Southern area of Lake Pátzcuaro, where leads the wetland, are alkaline $(332 \mathrm{mg}$ $\left.\mathrm{CaCO}_{3} \mathrm{~L}^{-1}\right)$, pH slightly alkaline, conductivity of $714.5 \mu \mathrm{S}$ $\mathrm{cm}^{-1}$, with a high concentration of nitrogen (total nitrogen $\left.=2.44 \mathrm{mg} \mathrm{L}^{-1}\right)$ and phosphorous poor $\left(\mathrm{TP}=0.21 \mathrm{mg} \mathrm{L}^{-1}\right)$, $\mathrm{BOD}_{5}$ of $15 \mathrm{mg} \mathrm{L}^{-1}$, and TSS of $668.49 \mathrm{mg} \mathrm{L}^{-1}$ (SánchezChávez et al., 2011).

\section{Sample collection}

Based on the Ramsar Wetland, south of the Pátzcuaro polygon (707 ha) and the wetland hydrological map scale 1:20; six transects were established from southwest to northeast direction. In each transect, two sampling points were selected based on (Fig. 1), which resulted in 12 points. The sampling points located at the beginning of each transect collected monthly (12 months) on the entry of water to the wetland watershed runoff (input), while the terminals were placed at the edge of Lake Pátzcuaro (output). The linear distance covered by each transects depended on its location; the maximum distance was 3.32 $\mathrm{km}$ in Transect 4, and the minimum distance was $1.54 \mathrm{~km}$ in Transect 6 . The average gradient at the beginning of each transect was $2.2 \%$ and $0.2 \%$ at the end. Sample collection was conducted from November 2011 to October 2012 (12 sampling months), and 144 samples were obtained from the two periods: the dry period, from November to May; the rainy period from June to October (Fig. 1). During the dry period, accumulated precipitation was 80 $\mathrm{mm}$, with an average runoff of $100.08 \mathrm{~m}^{3}$. During the rainy period, precipitation was $794.2 \mathrm{~mm}$, and 1488.98 $\mathrm{m}^{3}$ of runoff, with maximum rainfall of $325 \mathrm{~mm}$ in August (Fig. 2). In the field, water temperature, $\mathrm{pH}$ and conductivity (Conductronic model PC18, previously calibrated and equipped with a conductivity cell, $\mathrm{pH}$ electrode and integrated thermistor) were recorded for each sample site. Dissolved oxygen (DO) was recorded with previously calibrated and Winkler-modified yellow spring multiparametric equipment (Eaton et al., 1995). Moreover, surface water samples were collected and stored in polyethylene containers (capacity of $4 \mathrm{~L}$ ), were previously treated with $10 \%$ hydrochloric acid and rinsed with distilled water. These samples were transported to the laboratory in cold storage and filtrated (Whatman GF/F, with a pore size of $0.7 \mu \mathrm{m}$ ) for the subsequent analysis of nu- trients $\left(\mathrm{NO}_{3}^{-}, \mathrm{NO}_{2}^{-}, \mathrm{PO}_{4}^{3-}\right.$, and TP), except for TSS and the $\mathrm{BOD}_{5}$ and $\mathrm{COD}$.

\section{Chemical analysis}

Water samples were analyzed in triplicate in $24 \mathrm{~h}$. Determination of TP was carried out by the phosphomolybdate technique (Murphy and Riley, 1962), with prior digestion in a semi-automated autoclave. For $\mathrm{PO}_{4}{ }^{3-}$, the ascorbic acid technique was used (Eaton et al., 1995). $\mathrm{NO}_{2}{ }^{-}$was determined by the sulfanilamide hydrochloride solution technique, and $\mathrm{NO}_{3}^{-}$was established by the brucine acid technique (Eaton et al., 1995). The four variables were measured by a colorimetric method using a spectrophotometer, the Perkin Elmer Lambda 10UV/Vis model, after obtaining the calibration curves to calculate the corresponding concentrations. $\mathrm{BOD}_{5}$ was determined with the incubation technique and COD by the concentrated sulfuric acid digestion technique (Eaton et al., 1995). TSS were estimated by the gravimetric technique after filtering water samples with glass fiber filters (Whatman International Ltd., GF/C with a pore size of $0.45 \mu \mathrm{m}$ ), to be then dried at $105^{\circ} \mathrm{C}$ and weighed in an analytical balance to obtain a $0.01 \mathrm{mg}$ reading of precision (Strickland and Parsons, 1972). During the study, the chloride $\left(\mathrm{Cl}^{-}\right)$concentration was not analyzed. However, bibliog-
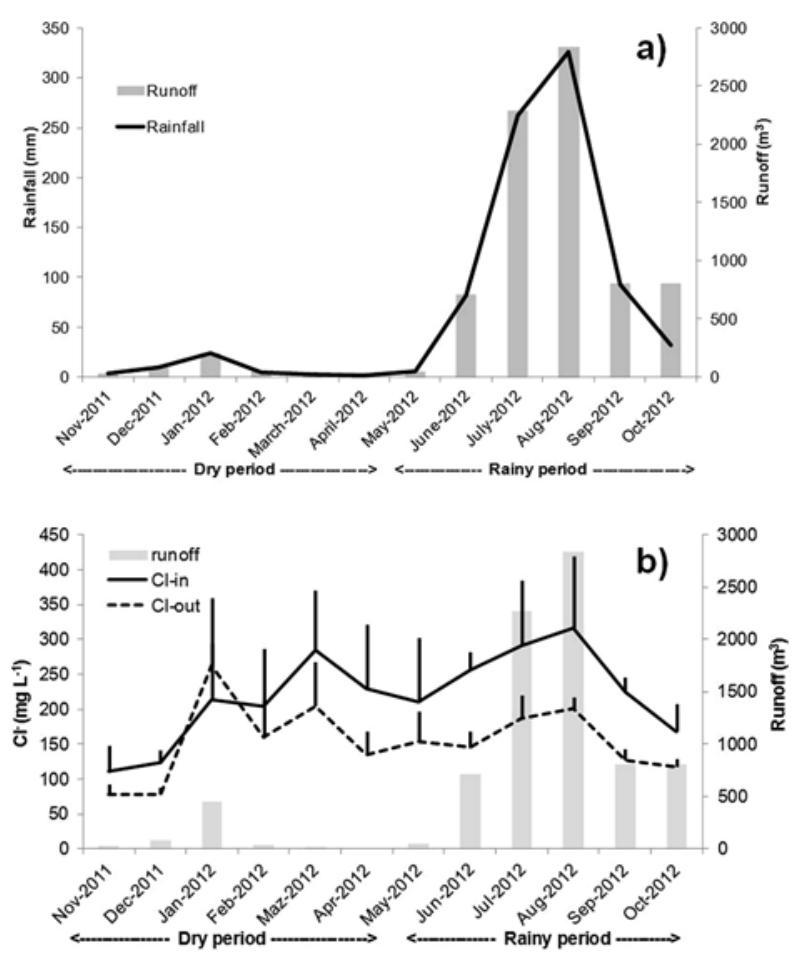

Fig. 2. Annual precipitation and runoff (a), and input and output of chloride $\left(\mathrm{Cl}^{-}\right)$concentrations (mean $+\mathrm{SD}$ ) (b), during the study period at the South Lake Pátzcuaro wetland. 
raphy data (Bischoff et al., 2004) from technical reports (SEPLADE, 2000; Aguillón et al., 2006) and our own data collected in south Pátzcuaro Lake area and at several points around the wetland were employed. These data covered a long period from 1999 to 2009 . Due to the high correlation between conductivity and $\mathrm{Cl}^{-}$concentration $\left(\mathrm{R}^{2}=0.96 ; \mathrm{P}<0.01 ; \mathrm{n}=25\right)$, the $\mathrm{Cl}^{-}$concentration for all the chloride samples was calculated with this equation: $y=0.2037 x-84.036$.

\section{Retention calculations}

Since there were no permanent streams that feed the wetland, surface runoff was calculated each month (12 months) by the indirect method of the monthly runoff $(\mathrm{Q}$ in $\mathrm{m}^{3} \mathrm{~s}^{-1}$ ) that the wetland receives from precipitation, without considering the interception of rain by vegetation and soil moisture. Calculation of the average surface runoff in the area is based on the estimate of the surface runoff from rain $(\mathrm{P})$ in $\mathrm{mm}$ that occurs in the study area (A) $\mathrm{km}^{2}$ by applying a runoff coefficient $(\mathrm{C})$, which varied from 0.1 to 1.0 depending on slope, soil texture (clay loam in our case) and land use. Finally, a correction factor of units $(\mathrm{F}=0.028)$ was applied in $\mathrm{m}^{3}$ ( $\mathrm{F}$ is a numerical constant of the resulting units which the variables are expressed) (Treviño et al., 2002; Viera-Briones et al., 2012) with the following equation:

$\mathrm{Q}=\mathrm{A} * \mathrm{C} * \mathrm{P} * \mathrm{~F}$

$\mathrm{Cl}^{-}$was used as a passive indicator as it undergoes dispersion, dilution and dissemination, but it is not easy to remove from solutions. Hence variations in the $\mathrm{Cl}^{-}$concentration allow the detection of possible dilution via lateral or subsurface water inputs or by the evapotranspiration concentration, which can alter the concentrations of nutrients and other elements (García-García et al., 2009). So retention (\%R), understood as the elimination percentage of different forms of nutrients $\left(\mathrm{NO}_{3}{ }^{-}\right.$, $\mathrm{NO}_{2}{ }^{-} ; \mathrm{PO}_{4}{ }^{3-}$ and TP and TSS), was calculated on each sampling date by considering the difference between the relationship of the input concentrations (Nutrient $/ \mathrm{Cl}^{-}$in) and the output concentration (Nutrient $/ \mathrm{Cl}^{-}$out ) in the wetland (Fleischer and Stibe, 1991; Jordan et al., 2007) following the formula (Trudell et al., 1986):

$\% \mathrm{R}=\left(1-\left(\right.\right.$ Nutrient $\left.\left.\left./ \mathrm{Cl}^{-}{ }_{\text {out }} / \mathrm{Nutrient} / \mathrm{Cl}^{-}{ }_{\text {in }}\right)\right) \times 100\right)$

A positive retention value means that the inflow $\mathrm{Nu}-$ trient $/ \mathrm{Cl}^{-}$ratio was higher than the outflow Nutrient $/ \mathrm{Cl}^{-}$ ratio, indicates that the wetland acts as a sink of nutrients. On the contrary, a negative retention value means that the outflow Nutrient $/ \mathrm{Cl}^{-}$ratio was higher than the inflow Nutrient $/ \mathrm{Cl}^{-}$ratio, indicates that the wetland acts as source of nutrients.

\section{Statistical analyses}

For the statistical analyses, the Minitab 16 software for Windows (Minitab Inc., State College, PA, USA) and SPSS (software ver. 19 for windows; SPSS Inc., Chicago, IL, USA) were used. To quantify the temporal variability of the input and output concentrations in the wetland of the different forms of nutrients $\left(\mathrm{NO}_{3}^{-}, \mathrm{NO}_{2}^{-}, \mathrm{PO}_{4}{ }^{3-}\right.$ and $\mathrm{TP})$ and TSS, the coefficient of variation (CV \%) was calculated. An analysis of variance (one-way ANOVA) was used for a factor $(\mathrm{P}=0.05)$ followed by a Tukey's test with a $95 \%$ confidence interval to determine annual and seasonal differences in the retention percentage $(\% \mathrm{R})$ during the dry (November-May) and rainy (June-October) periods, and the temporal variability in the wetland's environmental parameters. Finally, Spearman correlations analysis was applied to obtain the coefficient of correlation between $\% \mathrm{R}$ and the environmental variables in the wetland. Whenever necessary, the input and output nutrients concentration data were $\log (\mathrm{x}+1)$-transformed to ensure normality and homogeneity of variance.

\section{RESULTS}

\section{Seasonal characterization of inflow and outflow water}

The total runoff received by the wetland was $7899 \mathrm{~m}^{3}$. During the rainy period, runoff was higher $\left(7445 \mathrm{~m}^{3}, \mathrm{n}=5\right.$ months) than during the dry period $\left(453.8 \mathrm{~m}^{3}, \mathrm{n}=7\right.$ months). The maximum value was recorded in August $\left(2835 \mathrm{~m}^{3}\right)$ and the minimum one was recorded in April $\left(11.4 \mathrm{~m}^{3}\right)$ (Fig. 2). The ANOVA test did not show statistical differences between runoff and $\mathrm{Cl}^{-}$concentration (both input and output; $\mathrm{F}=3.30, \mathrm{P}>0.05$ ) throughout the year. The annual mean input $\mathrm{Cl}^{-}$concentration value was higher (219.45 $\left.\mathrm{mg} \mathrm{L}^{-1}\right)$ than for output $\left(154.33 \mathrm{mg} \mathrm{L}^{-1}\right)$. The input and output $\mathrm{Cl}^{-}$concentrations followed the same trend throughout the study period (Fig. 2), except in January when atypical precipitation was recorded, although they showed greater temporal variability $\left(\mathrm{CV}_{\mathrm{in}}=41.04\right.$ and $\mathrm{CV}_{\text {out }}=42.13, \mathrm{n}=12$, respectively; Tab. 1), which was maintained during both periods $\left(\mathrm{CV}_{\text {in }}=32.16, \mathrm{CV}_{\text {out }}=25.22\right.$ for the rainy period; $\mathrm{CV}_{\mathrm{in}}=45.86, \mathrm{CV}_{\text {out }}=51.46$ for the dry period; Tab. 2). The mean values for input water temperature, $\mathrm{pH}$ and conductivity were similar to the output ones (Tab. 1) and they all showed temporal variability $(\mathrm{CV}<30 \%)$, although statistically significant differences between input and output conductivity were found $(\mathrm{F}=24.74, \mathrm{P}=0.01)$. These variables maintained the same pattern during the rainy and dry periods (Tab. 2). Water temperature presented a low coefficient of variation in both the rainy and dry periods (Tab. 2). Similarly, a low variability was recorded for $\mathrm{pH}$ in both periods (Tab. 2), although a significant difference $(\mathrm{F}=4.50, \mathrm{p}=0.014)$ was detected between input and output during the rainy period. DO concentrations, $\mathrm{BOD}_{5}$ and $\mathrm{COD}$ showed low variabil- 
ity, for both input and output, during the study period (Tab. 1). DO showed the highest variability during the rainy period $\left(\mathrm{CV}_{\text {out }}=49.62 \%\right.$, Tab. 2$)$ and a significant difference was detected between input and output $(\mathrm{F}=6.13$, $\mathrm{p}=0.009$ ). Likewise, significant differences were observed between input and output for $\mathrm{BOD}_{5}$ and $\mathrm{COD}(\mathrm{F}=569.61$, $\mathrm{P}=0.001$ ) during the rainy period. The $\mathrm{BOD}_{5}$ values were always higher in inflow than in outflow, except for November and the end of the dry period (April and May) (Fig. 3). The inputs TSS were always higher than for output in both periods (Tab 2, Fig. 3). Regarding nutrient concentrations, the mean annual values for the input TP and $\mathrm{PO}_{4}{ }^{3-}$ concentrations in the wetland were almost 2fold higher than for output (Tab. 1), with higher temporal variability found for output $(\mathrm{CV}=67.3 \%$ and $\mathrm{CV}=67.57 \%$ ) than input ( $\mathrm{CV}=38.1 \%$ and $\mathrm{CV}=40.76 \%)$ (Tab. 1). Highest TP concentrations were found for input during the rainy period (Tab. 2), while the lowest were for output during the dry period (Tab. 2). This same trend was shown by the $\mathrm{PO}_{4}{ }^{3-}$ concentrations (Tab. 2), except in July $\left(237.95 \mu \mathrm{g} \mathrm{L}^{-1}\right)$ and August $\left(166.56 \mu \mathrm{g} \mathrm{L}^{-1}\right)$, when a higher $\mathrm{PO}_{4}^{3-}$ concentration was reported in output than in input (Fig. 3). ANOVA test indicated that TP $(\mathrm{F}=32.99$, $\mathrm{P}=0.001)$ and $\mathrm{PO}_{4}{ }^{3-}(\mathrm{F}=18.39, \mathrm{P}=0.007)$ differed significantly during the rainy and dry periods.

The mean annual value for $\mathrm{NO}_{2}^{-}$inputs was $50 \%$ higher than output (Tab. 1), and the coefficient of variation for $\mathrm{NO}_{2}^{-}$was greater $\left(\mathrm{CV}_{\mathrm{in}}=75.41 \%\right.$ and $\left.\mathrm{CV}_{\text {out }}=52.85 \%\right)$ than that reported for $\mathrm{NO}_{3}{ }^{-}\left(\mathrm{CV}_{\text {in }}=49.84 \%\right.$ and $\mathrm{CV}_{\text {out }}=45.49 \%$ ) (Tab. 1). Both the $\mathrm{NO}_{2}{ }^{-}$and $\mathrm{NO}_{3}{ }^{-}$concentrations presented significant differences between input and output $(\mathrm{F}=21.95$ and 85.85 respectively, $\mathrm{p}<0.05)$ and between rainy and dry periods $(\mathrm{F}=12.13, \mathrm{P}=0.001$; $\mathrm{F}=22.47, \mathrm{P}=0.001$ ). In both the rainy and dry periods, the mean input $\mathrm{NO}_{3}{ }^{-}$concentrations were higher than for out- put (Tab. 2). The $\mathrm{NO}_{3}{ }^{-}$concentrations were always higher for inflow than for outflow, except at the end of the dry period (April and May) (Fig. 3).

\section{Nutrients retention}

When considering all the sampling data, the mean annual retention $(\% \mathrm{R})$ for $\mathrm{TP}$ was $30.35 \%$, and the mean maximum retention was reported during the dry period (Tab. 3). Similarly, the mean maximum $\% \mathrm{R}$ for $\mathrm{PO}_{4}{ }^{3-}$ was obtained during the same period (Tab. 3). The net mean retention was $47.12 \%(\mathrm{n}=54)$ for TP and $43.87 \%(\mathrm{n}=48)$ for $\mathrm{PO}_{4}{ }^{3-}$, while no retention of TP occurred on the 18 sampling dates (mean export: $-19.93 \%$ ), nor of $\mathrm{PO}_{4}{ }^{3-}$ on the 24 sampling dates (mean export: -30.16\%) (Tab. 3). The mean annual retention for $\mathrm{NO}_{2}^{-}$was very low and was a negative mean value during the dry period $(-5.90 \%, \mathrm{n}=42)($ Tab. 3$)$. On 31 sampling dates ( $40 \%$ of all samples), no retention of $\mathrm{NO}_{2}{ }^{-}$took place (mean export: $-48.50 \%$; Tab. 3). The mean annual retention for $\mathrm{NO}_{3}{ }^{-}$was $17.56 \%$, with a maximum mean retention value recorded during the rainy period $(48.99 \%, n=30)$. The net retention for $\mathrm{NO}_{3}{ }^{-}$was $38.76 \%$ $(n=60)$, although the percentage of export was $-88.41 \%$ $(\mathrm{n}=12)$. The mean annual retention for TSS was positive $(14.68 \%)$ and the highest mean retention value was detected during the rainy period (Tab. 3). The mean value of net retention for TSS was $34.03 \%(\mathrm{n}=52)$. The temporal variability of the retention for $\mathrm{TP}$ and $\mathrm{PO}_{4}{ }^{3-}$ showed the same annual trend (Fig. 4), although the $\% \mathrm{R}$ for TP presented less variability $(\mathrm{CV}=42.9 \%)$ than for $\mathrm{PO}_{4}{ }^{3-}$ (CV=66.5\%).

During the dry period, the $\% \mathrm{R}$ for both parameters was positive, with a maximum of $82.19 \%$ for $\mathrm{PO}_{4}{ }^{3-}$ in January and of $69.59 \%$ for TP in November. Positive retention values were detected for both parameters in October, at the end of rainy period $(20.05 \%$ for TP and $19.74 \%$ for

Tab.1. Mean, maximum and minimum values of the different physico-chemical parameters measured in the input and output water of the South Lake Pátzcuaro wetland.

\begin{tabular}{|c|c|c|c|c|c|c|c|c|}
\hline \multirow[b]{2}{*}{$\mathrm{N}=72$} & \multicolumn{4}{|c|}{ Input } & \multicolumn{4}{|c|}{ Output } \\
\hline & Mean \pm SD & Max & Min & CV (\%) & Mean \pm SD & Max & Min & CV (\%) \\
\hline Water temperature $\left({ }^{\circ} \mathrm{C}\right)$ & $21.26 \pm 4.45$ & 32.60 & 14.00 & 20.91 & $20.67 \pm 4.27$ & 29.38 & 10.50 & 20.65 \\
\hline $\mathrm{pH}$ & $8.09 \pm 0.47$ & 9.70 & 7.00 & 5.83 & $8.25 \pm 0.45$ & 9.00 & 6.93 & 5.47 \\
\hline Conductivity $\left(\mu \mathrm{S} \mathrm{cm}^{-1}\right)$ & $1489.86 \pm 442.14$ & 2860.00 & 702.00 & 29.68 & $1170.20 \pm 319.22$ & 2545.90 & 672.00 & 27.28 \\
\hline $\mathrm{Cl}^{-}\left(\mathrm{mg} \mathrm{L}^{-1}\right)$ & $219.45 \pm 90.06$ & 498.50 & 59.00 & 41.04 & $154.33 \pm 65.02$ & 434.57 & 52.85 & 42.13 \\
\hline $\mathrm{DO}\left(\mathrm{mg} \mathrm{O}_{2} \mathrm{~L}^{-1}\right)$ & $6.02 \pm 2.02$ & 12.00 & 2.90 & 33.45 & $5.21 \pm 1.94$ & 9.17 & 1.30 & 37.19 \\
\hline $\mathrm{TP}\left(\mu \mathrm{g} \mathrm{L}^{-1}\right)$ & $534.30 \pm 203.60$ & 1156.00 & 70.20 & 38.10 & $236.20 \pm 159.00$ & 1001.00 & 31.30 & 67.30 \\
\hline $\mathrm{PO}_{4}{ }^{3-}\left(\mu \mathrm{g} \mathrm{L}^{-1}\right)$ & $198.64 \pm 80.96$ & 416.80 & 30.30 & 40.76 & $107.58 \pm 72.69$ & 409.20 & 3.79 & 67.57 \\
\hline $\mathrm{NO}_{2}^{-}\left(\mathrm{mg} \mathrm{L}^{-1}\right)$ & $0.10 \pm 0.07$ & 0.38 & 0.02 & 75.41 & $0.05 \pm 0.03$ & 0.16 & 0.01 & 52.85 \\
\hline $\mathrm{NO}_{3}^{-}\left(\mathrm{mg} \mathrm{L}^{-1}\right)$ & $7.81 \pm 3.89$ & 24.49 & 0.03 & 49.84 & $3.61 \pm 1.64$ & 10.73 & 0.20 & 45.49 \\
\hline $\mathrm{BOD}_{5}\left(\mathrm{mg} \mathrm{O}_{2} \mathrm{~L}^{-1}\right)$ & $245.60 \pm 81.12$ & 483.10 & 77.82 & 33.03 & $211.78 \pm 59.31$ & 379.33 & 77.82 & 28.00 \\
\hline $\operatorname{COD}\left(\mathrm{mg} \mathrm{O}_{2} \mathrm{~L}^{-1}\right)$ & $944.53 \pm 254.30$ & 1498.00 & 480.00 & 26.93 & $969.10 \pm 149.40$ & 1200.40 & 280.00 & 15.42 \\
\hline $\mathrm{TSS}\left(\mathrm{mg} \mathrm{L}^{-1}\right)$ & $416.85 \pm 144.30$ & 1009.00 & 10.80 & 34.63 & $228.00 \pm 108.70$ & 800.00 & 7.30 & 47.66 \\
\hline
\end{tabular}


$\left.\mathrm{PO}_{4}{ }^{3-}\right)$, and in June for TP (16.77\%; Fig. 4). The highest export values were found during the dry period $(-36.99 \%$ for TP in July and $-47.94 \%$ for $\mathrm{PO}_{4}{ }^{3-}$ in June). The $\mathrm{NO}_{2}{ }^{-}$retention values showed the highest temporal variability of all the nutrient forms $(\mathrm{CV}=122.1 \%) . \mathrm{NO}_{2}^{-}$retention remained below the $\mathrm{NO}_{3}^{-}$retention values almost all year, except in May (48.22\%) and October (66.61\%), when the highest $\mathrm{NO}_{2}^{-}$retention values were reported. The wetland retained $\mathrm{NO}_{3}{ }^{-}$throughout the year, except at the end of dry period (-93.51\% in April and -83.3\% in May) (Fig. 4). The highest $\mathrm{NO}_{3}{ }^{-}$retention value was detected in November $(72.89 \%)$. TSS showed high temporal variability $(\mathrm{CV}=99.4 \%)$. TSS were retained almost all year, except for three months during the dry period (November, December and April). The maximum TSS retention value was recorded in October (63.02\%; Fig. 4).

\section{Relationships between nutrients retention and environmental factors}

During the rainy period, TP retention correlated positively with input TP concentration and input TSS, and negatively with conductivity and input $\mathrm{BOD}_{5}$, while it correlated positively with input TP and negatively with input $\mathrm{BOD}_{5}$ during the dry period (Tab. 4). $\mathrm{PO}_{4}{ }^{3-}$ retention correlated positively with input for both $\mathrm{DO}$ and $\mathrm{NO}_{2}{ }^{-}$ during the rainy period $(\mathrm{P}<0.05)$, and correlated negatively with $\mathrm{pH}$ and conductivity. During the dry period, $\mathrm{PO}_{4}{ }^{3-}$ retention positively correlated only with TP input $(\mathrm{P}<0.05)$. (Tab. 4). $\mathrm{NO}_{2}{ }^{-}$retention correlated positively with the input for both $\mathrm{NO}_{2}^{-}$and $\mathrm{PO}_{4}{ }^{3-}$ during the rainy period and with the input $\mathrm{DO}$ and $\mathrm{NO}_{2}{ }^{-}$concentrations during the dry period. Moreover, it correlated significantly and negatively with $\mathrm{pH}$, water temperature and TSS input during the dry period, and only with TP input during the rainy period. $\mathrm{NO}_{3}{ }^{-}$retention correlated significantly and positively with the input for both the $\mathrm{NO}_{3}{ }^{-}$and $\mathrm{NO}_{2}{ }^{-}$concentrations during the dry period. Furthermore during this period, it correlated negatively with the inputs for both $\mathrm{PO}_{4}{ }^{3-}$ and $\mathrm{COD}$ and also with conductivity and TSS input during the dry period (Tab. 4). TSS retention correlated only negatively with conductivity during the rainy period, while it correlated positively with this parameter during the dry period and negatively with water temperature, $\mathrm{NO}_{2}^{-}$and $\mathrm{NO}_{3}^{-}$inputs.

\section{DISCUSSION}

The south Pátzcuaro Lake wetland, like other subtropical lakes and wetlands of high altitudes (Challenger, 1999; Bauer, 2005), presents two distinctively marked hydrological periods: a shorter rainy period (5 months) and a dry long-term period (7 months). However, unlike other subtropical wetlands that remain completely dry during an annual hydrological cycle phase (Neiff, 2001),

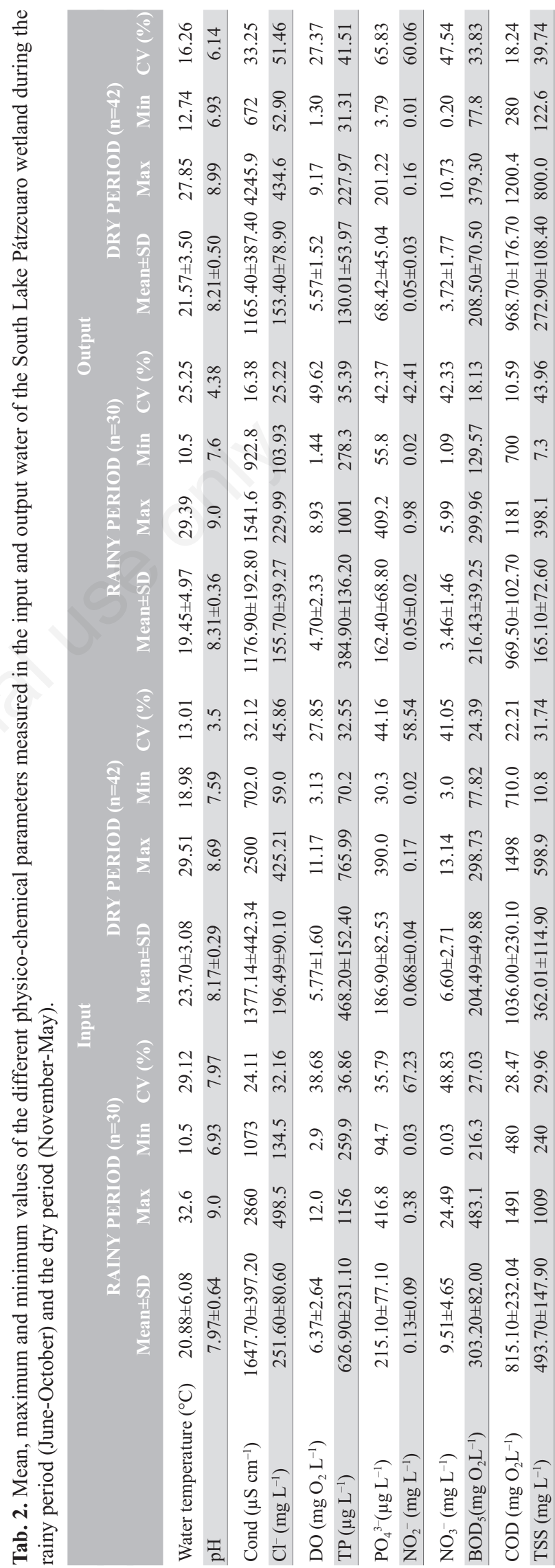



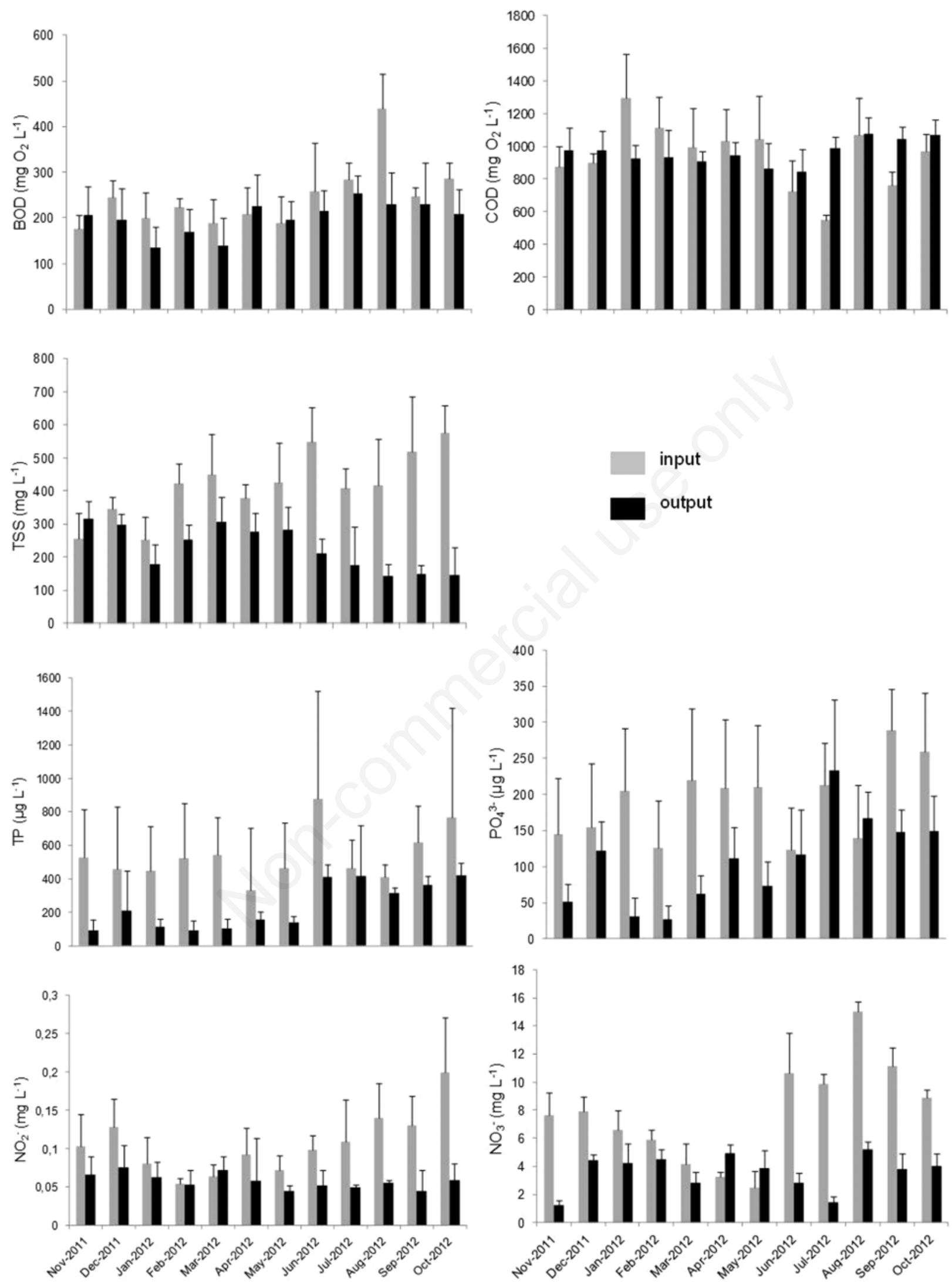

Fig. 3. Annual variation of the input (grey bars) and output (black bars) of $\mathrm{BOD}_{5}, \mathrm{COD}, \mathrm{TSS}, \mathrm{TP}, \mathrm{PO}_{4}{ }^{3-}, \mathrm{NO}_{2}^{-}$and $\mathrm{NO}_{3}^{-}$, concentrations $($ mean \pm SD) for the South Lake Pátzcuaro wetland. 
Pátzcuaro wetland maintains surface water throughout the year in spite of a long dry period. Since this wetland has no streams that provide a water surface flow, water comes from indirect natural recharge through rainfall runoff (Ruiz, 2003), which is characteristic of high altitude areas, igneous metamorphic soil and weather conditions (Alcalá and Custodio, 2008), which is the case of the Pátzcuaro wetland. Therefore during the rainy period, the wetland accumulates about $94 \%$ of total annual rainfall runoff (Fig. 1), which allows a constant layer of water to remain
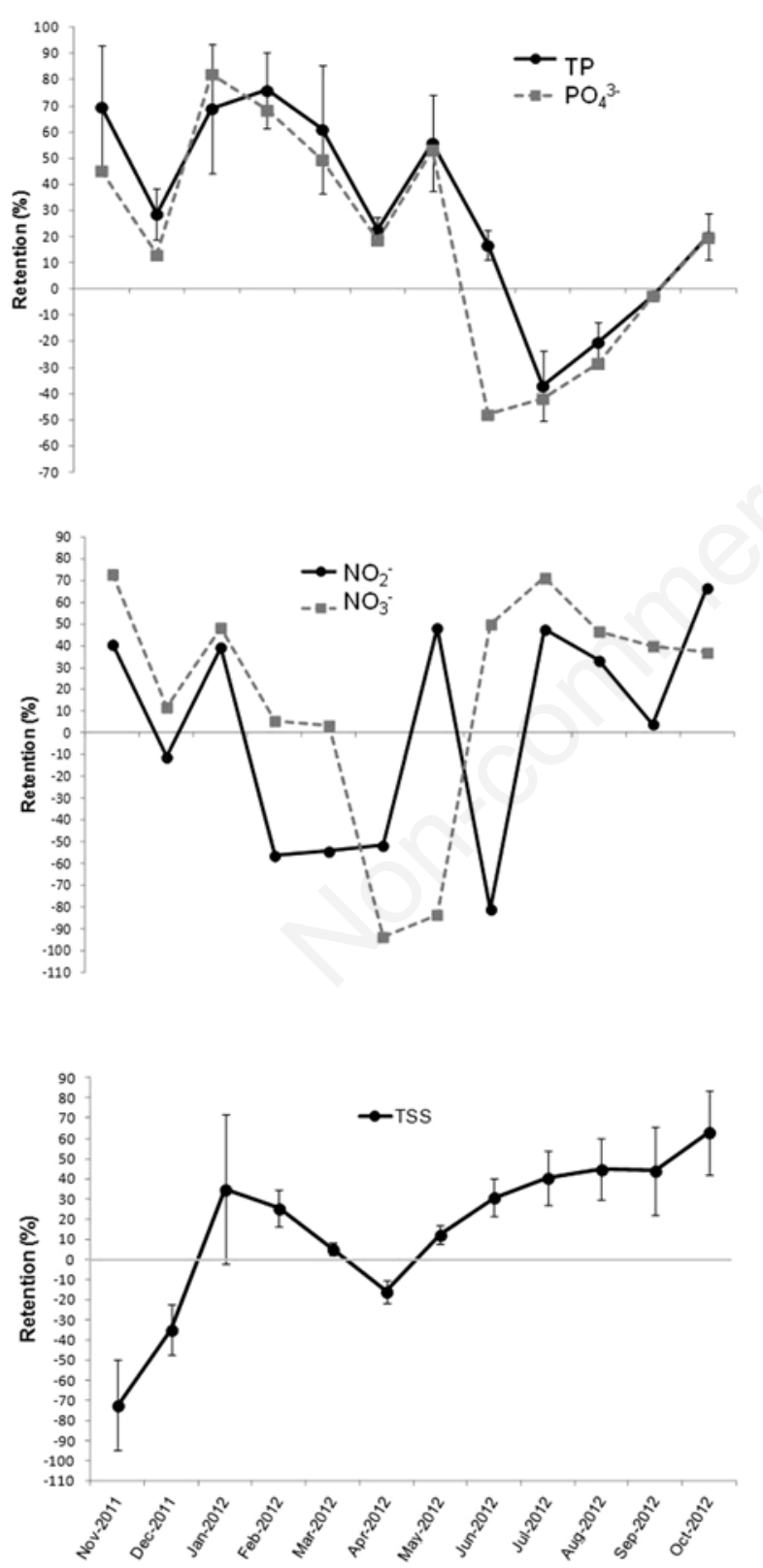

Fig. 4. Annual variation of the TP, $\mathrm{PO}_{4}^{3-}, \mathrm{NO}_{2}^{-}, \mathrm{NO}_{3}^{-}$, and TSS retention efficiencies $( \pm \mathrm{SD})$ in the South Lake Pátzcuaro wetland. throughout the year. Indeed precipitation is the main source for maintaining the water table in the wetland. However other sources, such as lateral or subsurface water inputs or losses like evapotranspiration, can be important factors that explain the hydrological dynamics of wetlands (Sabater et al., 2003). As chloride is a conservative element (Álvarez-Rogel et al., 2006), $\mathrm{Cl}^{-}$concentration was used as an indirect indicator to detect possible water inputs and/or outputs to wetlands (Simmons et al., 1992; Sabater et al., 2003). Our results indicate that $\mathrm{Cl}^{-}$concentration in inflow was always higher than in outflow (except January because of atypical rain, Fig. 2). Thus we assumed that the dilution caused by the inflow of subsurface water diffuse or by discharges from springs was not found to be relevant and did not affect nutrient concentration. The South Lake Pátzcuaro wetland has proved to efficiently lower nutrient concentrations (TP, $\mathrm{PO}_{4}{ }^{3-}, \mathrm{NO}_{2}{ }^{-}$ and $\mathrm{NO}_{3}^{-}$), although its effectiveness differs depending on the nutrient species and the period of year considered (Schade et al., 2002; Vellidis et al., 2003). We found a mean annual reduction of $30.35 \%$ for TP and $19.19 \%$ for $\mathrm{PO}_{4}{ }^{3-}$, but these reductions increase significantly during the dry period $\left(55.32 \%\right.$ for TP and $47.3 \%$ for $\mathrm{PO}_{4}{ }^{3-}$; Tab. 3 ). On the contrary, both forms were exported during the rainy period. These retention values are similar to those reported in the literature. According to Kadlec and Knight (1996), mean retention percentages by constructed wetlands receiving municipal wastewaters were 34\% for TP and $41 \%$ for $\mathrm{PO}_{4}{ }^{3-}$. Mitsch et al. (1995) found that the average TP concentration decreased by $64-92 \%$ in four constructed freshwater riparian marshes of low flow in northeastern Illinois. In a Louisiana forested waste-water treatment wetland, Blahnik and Day (2000) reported highly variable retention values for $\mathrm{PO}_{4}{ }^{3-}$ (3-50\%). Knox et al. (2008) obtained reductions of $35 \%$ and $42 \%$ for TP and $\mathrm{PO}_{4}{ }^{3-}$, respectively in a natural wetland situated in Northern California.

The pattern of retention followed by the two $\mathrm{N}$ forms differs. The highest mean annual reduction is reported for $\mathrm{NO}_{3}{ }^{-}(17.56 \%)$, whereas annual $\mathrm{NO}_{2}{ }^{-}$reduction is only $2.45 \%$. However, unlike $\mathrm{TP}$ and $\mathrm{PO}_{4}{ }^{3-}, \mathrm{NO}_{3}{ }^{-}$reduction increased significantly during the rainy period to $48.99 \%$. In general, these retention values are lower than those reported in the literature. In a forested wetland of Louisiana, Blahnik and Day (2000) found retention $\mathrm{NO}_{3}{ }^{-}$to lie between 32\% and 95\%; Knox et al. (2008) reported a 60\% reduction in a Californian wetland, and studies into riparian forests have indicated high retention for $\mathrm{NO}_{3}^{-}$(over 80\%; Lowrance et al., 1984; Jordan et al., 1993). For TSS, we obtained mean annual retention values of $14.68 \%$, but this retention increased to $44.52 \%$ during the rainy period. During the dry period, the wetland exported TSS (mean: $-6.63 \%)$. These reduced TSS values are lower than those described in the literature. In a forested wetland of 
Louisiana, Blahnik and Day $(2000)$ reported retention values of between $48 \%$ and $91 \%$, and Knox et al. (2008) cited $77 \%$ in a natural California wetland. In constructed wetlands, reductions of $68 \%$ have been reported (Kadlec and Knight, 1996).

The nutrients retention in the Pátzcuaro wetland clearly shows its dependence on the hydrological cycle (Wetzel, 2001; Hakanson, 2004; AlMaarofi et al., 2013). $\mathrm{P}$ retention in wetlands is difficult to explain given the complex interactions taking place between hydrological and biogeochemical transformations, including assimilation by plants through photosynthesis (Hoffman et al., 2009; González-Alcaraz et al., 2012). For TP and $\mathrm{PO}_{4}{ }^{3-}$, the highest retention values were recorded during the dry period (Fig. 4). During this dry period, the residence time of low inflow water increased, which facilitates P retention by soil, this being one of the main mechanism involved in $\mathrm{PO}_{4}{ }^{3-}$ retention in wetlands (González-Alcaraz et al., 2012; Hoffman et al., 2012). Moreover, in the range of $\mathrm{pH}$ levels measured in the Pátzcuaro wetland (Tab. 2), dissolved phosphorus can precipitate as insoluble $\mathrm{Ca}$ or
Mg phosphates, or adsorbed as carbonates (Alvarez-Rogel et al., 2006). Additionally, P retention is related with uptake by emerging dense macrophyte communities that cover the wetland (Gagnon et al., 2012). Gómez et al. (2001) found that Phragmites australis was highly effective in the remove of phosphorus from the water in an artificial wetland, although high densities not improve nutrient retention. Besides the translocation of nutrients from shoots and leaves to roots during autumn reported by Meuleman et al. (2002) in P. australis, indicate that the response of the aquatic vegetation in a wetland may be influence by season of the year (Alvarez-Rogel et al., 2006). Both TP and $\mathrm{PO}_{4}{ }^{3-}$ retentions also depend indirectly on organic matter (Bruland and Richardson, 2006). In fact during the dry period, we found negative and significantly correlations between $\% \mathrm{R}$ of TP and $\mathrm{BOD}_{5}$ input (Tab. 4).

During the rainy period, the Pátzcuaro wetland exports $\mathrm{TP}$ and $\mathrm{PO}_{4}{ }^{3-}$ (Fig. 4), when the highest inflow concentrations are found (Tab. 2) and high inflow water and low residence time of water occurs. In a wetland of southern Spain was reported that during rainy periods, the effec-

Tab. 3. Total retention efficiency (\%) during the rainy and the dry periods, and net retention and export for the nutrients and TSS recorded in the South Lake Pátzcuaro wetland.

\begin{tabular}{|c|c|c|c|c|c|c|c|c|c|c|}
\hline & \multicolumn{2}{|c|}{$\begin{array}{l}\text { Total } \\
n=72\end{array}$} & \multicolumn{2}{|c|}{$\begin{array}{c}\text { Rainy period } \\
n=30\end{array}$} & \multicolumn{2}{|c|}{$\begin{array}{l}\text { Dry period } \\
\qquad n=42\end{array}$} & \multicolumn{2}{|c|}{ Net retention } & \multicolumn{2}{|c|}{ Export } \\
\hline & $\mathbf{R}(\%)$ & SD & R (\%) & SD & $\mathbf{R}(\%)$ & SD & $\mathbf{R}(\%)$ & SD & R (\%) & SD \\
\hline $\mathrm{TP}\left(\mu \mathrm{g} \mathrm{L}^{-1}\right)$ & 30.35 & 38.82 & -4.59 & 23.43 & 55.32 & 26.27 & $47.12(\mathrm{n}=54)$ & 28.01 & $-19.93(n=18)$ & 16.72 \\
\hline $\mathrm{PO}_{4}^{3-}\left(\mu \mathrm{g} \mathrm{L}^{-1}\right)$ & 19.19 & 43.37 & -20.18 & 27.63 & 47.32 & 27.79 & $43.87(n=48)$ & 27.60 & $-30.16(n=24)$ & 20.91 \\
\hline $\mathrm{NO}_{2}^{-}\left(\mathrm{mg} \mathrm{L}^{-1}\right)$ & 2.45 & 50.83 & 14.14 & 54.02 & -5.90 & 47.32 & $40.97(n=41)$ & 20.82 & $-48.50(n=31)$ & 28.76 \\
\hline $\mathrm{NO}_{3}^{-}\left(\mathrm{mg} \mathrm{L}^{-1}\right)$ & 17.56 & 54.15 & 48.99 & 18.88 & -4.88 & 59.88 & $38.76(n=60)$ & 27.14 & $-88.41(n=12)$ & 16.47 \\
\hline $\mathrm{TSS}\left(\mathrm{mg} \mathrm{L}^{-1}\right)$ & 14.68 & 40.70 & 44.52 & 18.96 & -6.63 & 38.69 & $34.03(\mathrm{n}=52)$ & 23.16 & $-39.29(\mathrm{n}=20)$ & 28.40 \\
\hline
\end{tabular}

Tab. 4. Spearman correlation coefficients for the retention efficiency of the nutrients and environmental factors measured during the study period at the South Lake Pátzcuaro wetland.

\begin{tabular}{|c|c|c|c|c|c|c|c|c|c|c|}
\hline & \multicolumn{5}{|c|}{ Rainy period (n=30) } & \multicolumn{5}{|c|}{ Dry period $(\mathrm{n}=42)$} \\
\hline & TP $\% R$ & $\mathrm{PO}_{4}{ }^{3-} \% \mathrm{R}$ & $\mathrm{NO}_{2}^{-} \% \mathrm{R}$ & $\mathrm{NO}_{3}^{-} \% \mathrm{R}$ & TSS $\% \mathbf{R}$ & TP $\% R$ & $\mathrm{PO}_{4}^{3-} \% \mathrm{R}$ & $\mathrm{NO}_{2}^{-} \% \mathrm{R}$ & $\mathrm{NO}_{3}^{-} \% \mathrm{R}$ & TSS $\% \mathbf{R}$ \\
\hline Water temperature $\left({ }^{\circ} \mathrm{C}\right)$ & & & & & & & & $-0.424^{* *}$ & & $-0.403^{* *}$ \\
\hline $\mathrm{pH}$ & & $-0.543^{* *}$ & & & & & & $-0.429^{* *}$ & & \\
\hline Conductivity $\left(\mu \mathrm{S} \mathrm{cm}^{-1}\right)$ & $-0.553^{* *}$ & $-0.734^{* *}$ & & & $-0.421^{*}$ & & & & $-0.502^{* *}$ & $0.306^{*}$ \\
\hline $\mathrm{DO}\left(\mathrm{mg} \mathrm{O}_{2} \mathrm{~L}^{-1}\right)$ & & $0.409^{*}$ & & & & & & $0.460^{* *}$ & & \\
\hline Input $\mathrm{TP}\left(\mu \mathrm{g} \mathrm{L}^{-1}\right)$ & $0.752^{* *}$ & & $-0.414^{*}$ & & & $0.531^{* *}$ & $0.325^{*}$ & & & \\
\hline Input $\mathrm{PO}_{4}{ }^{3-}\left(\mu \mathrm{g} \mathrm{L}^{-1}\right)$ & & & $0.377^{*}$ & $-0.390^{*}$ & & & & & & \\
\hline Input $\mathrm{NO}_{2}^{-}\left(\mathrm{mg} \mathrm{L}^{-1}\right)$ & & $0.438^{*}$ & $0.722^{* *}$ & & & & & $0.368^{*}$ & $0.466^{* *}$ & $-0.385^{*}$ \\
\hline Input $\mathrm{NO}_{3}^{-}\left(25 \mathrm{mg} \mathrm{L}^{-1}\right)$ & & & & & & & & & $0.722^{* *}$ & $-0.393^{* *}$ \\
\hline Input $\mathrm{BOD}_{5}\left(\mathrm{mg} \mathrm{O}_{2} \mathrm{~L}^{-1}\right)$ & $-0.379^{*}$ & & & & & $-0.330^{*}$ & & & & \\
\hline Input $\mathrm{COD}\left(\mathrm{mg} \mathrm{O}_{2} \mathrm{~L}^{-1}\right)$ & & & & $-0.395^{*}$ & & & & & & \\
\hline Input TSS (mg L $\left.{ }^{-1}\right)$ & $0.502^{* *}$ & & & & & & & $-0.407^{* *}$ & $-0.636^{* *}$ & \\
\hline
\end{tabular}

\footnotetext{
$* P<0.05 ; * * P<0.01$.
} 
tiveness to reduce $\mathrm{P}$ concentrations diminishes (ÁlvarezRogel et al., 2006). The rainy period at Pátzcuaro occurs in summer months when the highest temperatures are recorded and coincide with the senescence of wetland plants (Raisin and Mitchell, 1995). Hence both the high inflow P concentration from runoff due to the anthropogenic activities (mainly organic effluents and diffuse source from agriculture) and plant biomass accrual can reduce a wetland's capacity to process $P$. In fact we found positive and significant correlations between $\% \mathrm{R}$ of TP and both the input concentrations of TP and TSS (Tab. 4).

The seasonal pattern observed for nitrogen retention in the Pátzcuaro wetland is the opposite to $\mathrm{P}$ retention (Fig. 4). We found the highest retention values for both $\mathrm{NO}_{2}{ }^{-}$and $\mathrm{NO}_{3}{ }^{-}$during the rainy period. This pattern is unlike that which occurs in temperate environments (Fisher and Acreman, 2004), where the highest nutrient retention occurs in autumn to coincide with periods of increased precipitation and flow. The main $\mathrm{NO}_{3}{ }^{-}$retention processes are denitrification, plant uptake and microbial immobilisation (Reddy and Patrick, 1984; Groffman et al., 1992), whereas mineralisation of organic matter and its subsequent nitrification can result in the release of $\mathrm{NO}_{3}^{-}$ (Schade et al., 2002). Several authors have reported that denitrification can be especially important in aquatic ecosystems where fine sediments, high $\mathrm{NO}_{3}{ }^{-}$concentration, organic carbon availability, low redox potential and high water temperature exist (Inwood et al., 2007; Pinay et al., 2007). During the rainy period, we found that highest inflow $\mathrm{NO}_{3}{ }^{-}$concentrations and water temperatures were at their highest. Despite us not finding a correlation between water temperature and $\% \mathrm{R} \mathrm{NO}_{3}{ }^{-}$, the high values of $\mathrm{NO}_{3}{ }^{-}$inflow concentration recorded throughout the year suggest that denitrification may be the main removal process of nitrogen in the Pátzcuaro wetland. Denitrification can increase when flow rates through wetland is low and residence time is high (Garcia-Garcia et al., 2009), which occur in the Pátzcuaro wetland. In fact, except for two months at the end of the dry period (April and May), the Pátzcuaro wetland actively retained $\mathrm{NO}_{3}^{-}$(Fig. 4). Seasonal $\mathrm{NO}_{2}^{-}$retention dynamics is more difficult to explain. During the dry period, significantly and positive correlations were found between $\% \mathrm{R} \mathrm{NO}_{2}^{-}$and $\mathrm{DO}$ and $\mathrm{NO}_{2}^{-}$inflow concentration, which suggest that nitrification, determined by oxygen availability, may be the dominant process that increases $\mathrm{NO}_{3}{ }^{-}$concentration. Indeed a positive and significant correlation was found between $\% \mathrm{R} \mathrm{NO}_{3}{ }^{-}$and $\mathrm{NO}_{2}{ }^{-}$concentration input during this period. Typically, wetlands have been associated with reduced $\mathrm{N}$ loading rather than functioning to reduce $\mathrm{P}$ loading (Richardson, 1985; Fisher and Acreman, 2004). However, our results indicate that the Pátzcuaro wetland is more efficient at removing $\mathrm{P}$ than $\mathrm{N}$, perhaps because significant amounts of $\mathrm{P}$ are stored by sedimentation (Johnston,
1991) and retained by clay particles (Craft and Casey, 2000). The TSS input into the Pátzcuaro wetland reached its maximum during the rainy period (mean $\mathrm{TSS}=493.7$ $\mathrm{mg} \mathrm{L}^{-1}$; Tab. 2), when the massive influx of sediment from the drainage basin of the wetland takes place (Jørgensen, 2003; Beltran-Vargas and Rangel-Ch., 2012) and re-suspension of sediments occurs. However, we also detected maximum retention during this period (44.52\%; Tab. 3), probably because of the retention effect of emerging dense macrophyte communities that cover the wetland, as shown in other studies at similar latitudes (Abernethy, 1980). During the dry period, when the water flow speed slowed down and the water residence time was prolonged, TSS input lowered (Ockenden et al., 2012). TSS retention in the Pátzcuaro wetland is a response to both low-speed hydraulics, which results in a laminar flow, and resistance offered by roots and floating plants.

\section{CONCLUSIONS}

According to the data reported by different authors, the Pátzcuaro Lake has undergone very marked environmental degradation in the last 50 years (García-Villanueva, 2007; Bravo-Inclán et al., 2012).

Among the various causes, we find that diffuse pollution from agricultural areas is one of the most important impacts (Mijangos-Carros et al., 2008). One of the most relevant services provided by natural wetlands is their innate self-purification capacity. Hence the conservation and restoration of the Pazcuaro wetland are an excellent opportunity to make the best of its ability as a natural filter of the runoff water that the Pátzcuaro Lake receives. Despite Pátzcuaro wetland having been submitted to alterations, its ability to control nutrients has not become worse, as this study shows.

\section{ACKNOWLEDGMENTS}

The results of this study have been funded by Project HH09 of the National Commission of Biodiversity (CONABIO), Mexico. Thanks go to the working group on Earth Sciences of the INIRENA-University Michoacana of San Nicolas de Hidalgo for its support and collaboration in this work, and also to the biologist Raul Santos for his major contribution to this work. We also thank Helen Warburton for revising the English. We thank three anonymous reviewers for their valuable comments.

\section{REFERENCES}

Abernethy CL, 1980. Problems of soils erosion and sedimentation in the context of population growth and economic development. Proc. Seminar IAHR/UNESCO on Hydraulic Research and River Basin development in Africa, Nairobi.

Aguillón JE, Alatorre FC, Cruickshank VC Gamiño B, Martínez JL, Mendoza R, Monje I, Solís R, Tripp M. 2006. [Diagnós- 
tico energético e hidráulico del estado de Michoacán].[Book in Spanish]. CIDEM \& Morevallado,. Morelia: 211 pp.

Alcalá FJ, Custodio E, 2008. [Flujo de cloruro por la escorrentía directa en España].[Article in Spanish]. Ingeniería Agua 15:5-11.

AlMaarofi SS, Douabul AAZ, Warner BG, Taylor WD, 2013. Phosphorus and nitrogen budgets of the Al-Hawizeh marshland after re-flooding. Hydrobiologia 721:155-164.

Álvarez-Rogel J, Jiménez-Cárceles FJ, Nicolás CE, 2006. Phosphorus and nitrogen content in the water of a coastal wetland in the Mar Menor lagoon (SE Spain): relationships with effluents from urban and agricultural areas. Water Air Soil Poll. 173:21-38.

Ayala RGL, Ruiz SG, Chacón TA, Rendón LMB, Rosas MC, 2008. [Efectos de la dinámica física sobre el manejo del litoral lacustre de un lago volcánico, p. 244-247].[Article in Spanish]. Proc. VII Cong. Int. XIII Nat. and III Regional Ciencias Ambientales. Sonora, México.

Bauer CJ, 2005. In the image of the market: the Chilean model of water resources management. Int. J. Water 3 146-165.

Beltran-Vargas JE, Rangel-Ch JO, 2012. [Modelación dinámica de los sólidos suspendidos totales en el humedal Jaboque, Bogotá (Colombia)].[Article in Spanish]. Colombia Forestal 15:191-205.

Bernal-Brooks F, 2002. Classic studies of lakes and reservoirs across Mexico. LakeLine 22: 4-27.

Bernal-Brooks F, Dávalos-Lind L, Lind OT, 2003. Seasonal and special variation in algal growth and growth-limiting nutrients in a shallow endorheic lake: Lake Pátzcuaro (Mexico). Lake Reserv. Manage. 8:83-93.

Bischoff JL, Israde-Alcantara I, Garduño-Monroy VH, Shanks III C, 2004. The springs of lake Pátzcuaro: chemistry, saltbalance, and implications for the water balance of the lake. Appl. Geochem. 19:1827-1837.

Blahnik T, Day J, 2000. The effects of varied hydraulic and nutrient loading rates on water quality and hydrologic distributions in a natural forested treatment wetland. Wetlands 2048-61.

Bravo-Espinoza M, Fregoso-Tirado E, Medina-Orozco LE, 2006. [Parámetros de erosionabilidad del modelo WEPP para andosoles con uso pecuario en la Cuenca del Lago de Pátzcuaro, Michoacán].[Article in Spanish]. Técnica Pecuaria en México 44:129-141.

Bravo-Inclán L, Tomasini-Ortiz AC, Sánchez-Chávez JJ, MoellerChávez G, 2012. [Estudio de eutrofización del Lago de Pátzcuaro, Mich., y su relación con los florecimientos de cianobacterias].[Article in Spanish]. Proc. XXII Nat. Cong. Hidráulica, Acapulco. Available from: http://www.revistatlaloc.org.mx/amh_congreso/articulos/InfraestructuraParaAba stecimientoySaneamientoDelAgua/286art_bil\%5B1\%5D.pdf

Bruland GL, Richardson CJ, 2006. An assessment of the phosphorus retention capacity of wetlands in the Painter Creek watershed, Minnesota, USA. Water Air Soil Poll. 171:169-184.

Chacón-Torres A, 1993. [Pátzcuaro, Un lago amenazado: Bosquejo limnológico. Secretaria de difusión cultural].[Book in Spanush]. Editorial Universitaria,: 144 pp.

Chacón-Torres A, Múzquiz-Iribe E, 1997. Climatic trends, water balance and Lake Pátzcuaro, a tropical high altitude lake. Quatern. Int. 43:43-51.

Challenger A, 1999. [Los humedales y el cambio climático].[In
Spanish]. Available from: http://www.inecc.gob.mx/descargas/emc/der_anexo3.pdf

Costanza R, D'Arge R, De Groot R, Farber S, Grasso M, Hannon B, Limburg K, Naeem S, O’Neill RV, Paruelo J, Raskin RG, Sutton P, van den Belt M, 1997. The value of the world's ecosystem services and natural capital. Nature 387:253-260.

Conley DJ, Paerl HW, Howarth RW, Boesch DF, Seitzinger SP, Havens KE, Lancelot C, Likens GE, 2009. Controlling eutrophication: nitrogen and phosphorus. Science 323:10141015.

Craft CB, Casey WP, 2000. Sediment and nutrient accumulation in floodplain and depressional freshwater of Georgia, USA. Wetlands 20:323-332.

Eaton DA, Clesceri LS, Greenberg EA, 1995. Standard methods for the examination of water and wastewater. American Public Health Association, Washington.

Fleischer S, Stibe L, 1991. Drainage basin management-reducing river transported nitrogen. Verh. Int. Ver. Theor. Angew. Limnol. 24:1753-1755.

Fisher J, Acreman MC, 2004. Wetland nutrient removal: a review of the evidence. Hydrol. Earth Syst. Sci. 8:673-685.

Gagnon V, Chazarenc F, Koiv M, Brisson J, 2012. Effect of plant species on water quality at the outlet of a sludge treatment wetland. Water Res. 46:5305-5315.

García-García V, Gómez R, Vidal-Abarca MR, Suárez ML, 2009. Nitrogen retention in natural Mediterranean wetlandstreams affected by agricultural runoff. Hydrol. Earth Syst. Sci. 13:2359-2371.

García-García V, Gómez R, Vidal-Abarca MR, Suárez ML, 2013. Subsurface N retention in two Mediterranean wetland-streams affected by agricultural runoff. Wetlands 33:597-608.

García-Villanueva NH, 2007. Memoria ilustrada del programa para la recuperación ambiental de la cuenca del lago de Pátzcuaro. Avances 2003-2007].[Book in Spanish].Fundación Gonzalo Río Arronte / Instituto Mexicano de Tecnología del Agua (FGRA-IMTA: 144 pp.

Garduño-Monroy VH, Chávez-Hernández J, Aguirre-González J, Vázquez-Rosas R, Mijares H, Israde-Alcántara I, Hernández-Madrigal VM, Rodríguez-Pascua MA, Pérez R, 2009. [Zonificación de los periodos naturales de oscilación superficial en la ciudad de Pátzcuaro, Mich., México, con base en microtremores y estudios de paleosismología].[Article in Spanish]. Rev. Mex. Cienc. Geol. 26:623-637.

Gómez R, Suarez ML, Vidal-Abarca MR, 2001, The performance of a multi-stage system of constructed wetland for urban waste-water treatment in semiarid region of SE Spain. Ecol. Eng. 16:501-517.

González-Alcaraz MN, Egea C, Jiménez-Cárceles FJ, Párraga I, María-Cervantes A, Delgado MJ, Álvarez-Rogel J, 2012. Storage of organic carbon, nitrogen and phosphorus in the soil-plant system of Phragmites australis stands from a eutrophicated Mediterranean salt marsh. Geoderma 185186:61-72.

Groffman PT, Gold AJ, Simmons RC, 1992. Nitrate dynamics in riparian forest: microbial studies. J. Environ. Qual. 21: 666-671.

Hakanson L, 2004. Lakes: forms and function. Blackburn Press, Caldwell: $201 \mathrm{pp}$.

Hoffmann CC, Kjaergaard C, Uusi-Kämppä J, Hansen HC, Kro- 
nvang B, 2009. Phosphorus retention in riparian buffers: review of their efficiency. J. Environ. Qual. 38:1942-1955.

Hoffmann CC, Heiberg L, Audet J, Schønfeldt B, Fuglsang A, Kronvang B, Ovesen NB, Kjaergaard C, Hansen HCB, Jensen HS, 2012. Low phosphorus release but high nitrogen removal in two restored riparian wetlands inundated with agricultural drainage water. Ecol. Eng. 46:75-87.

Huerto-Delgadillo R, García AA, 2011. [Evaluación y análisis de la vegetación acuática y bases para su control, p 49-86]. In: D.R. Huerto, V.S. Vargas and P.C. Ortiz (eds.), [Estudio ecosistémico del lago de Pátzcuaro: Aportes en gestión ambiental para el fomento del desarrollo sustentable].[Book in Spanish]. Instituto de Tecnología del Agua.

INEGI, 2008a. [Proyecto de Hidrología Superficial: Serie I: México / Instituto Nacional de Estadística, Geografía e Informática. No. de cat. 224561].[In Spanish]. Instituto Nacional de Estadística, Geografía e Informática Aguascalientes.

INEGI, 2008b. [Estudios de la climatología en México/ Coordinación General de los Servicios Nacionales de Estadística Geografía e Informática. No. de cat. 230944].[In Spanish]. Instituto Nacional de Estadística, Geografía e Informática, Aguascalientes.

Inwood SE, Tank JL, Bernot MJ, 2007. Factors controlling sediment denitrification in Midwestern streams of varying land use. Microb. Ecol. 53:247-258.

Johnston CA, 1991. Sediment and nutrient retention by freshwater wetlands: effects on surface water quality. Crit. Rev. Env. Sci. Tec. 21:491-565.

Jordan TE, Correll DL, Weller DE, 1993. Nutrient interception by a riparian forest receiving inputs from adjacent cropland. J. Environ. Qual. 22:467-473.

Jordan T, Simpson TW, Weammert SE, 2007. Wetland restoration and wetland creation best management practices: Definition and nutrient and sediment reduction efficiencies for use in calibration of the phase 5.0 of the Chesapeake Bay Program Watershed model. Available from: http://www. chesapeake.org/pubs/238_2008.pdf

Jørgensen SE, 2003. The application of models to find the relevance of residence time in lake and reservoir management. J. Limnol. 62:16-20.

Junk WJ, 2002. Long-term environmental trends and the future of tropical wetlands. Environ. Conserv. 29:414-435.

Kadlec RH, Knight RL, 1996. Treatment wetlands. Lewis Publ., Boca Raton: 893 pp.

Knox AK, Dahlgren RA, Tate KW, Atwill ER, 2008. Efficacy of natural wetlands to retain nutrient, sediment and microbial pollutants. J. Environ. Qual. 37:1837-1846.

Kopacek J, Hejzlar J, Posch M, 2013. Quantifying nitrogen leaching from diffuse agricultural and forest sources in a large heterogeneous catchment. Biogeochemistry 115:149-165.

Landgrave R, Moreno-Casasola P, 2012.[ Evaluación cuantitativa de la pérdida de humedales en México].[Article in Spanish]. Investigación Ambiental Ciencia y Política Pública 4:19-35.

Lowrance R, Todd R, Fail J, Hendrickson Jr O, Leonard R, Asmussen L, 1984. Riparian forests as nutrient filters in agricultural watersheds. BioScience 34:374-377.

McInnes RJ, 2013. Recognizing ecosystem services from wetlands of international importance: an example from Sussex, UK. Wetlands 33:1001-1017.
Meuleman AF, Beekman J, Verhoeven JTA, 2002. Nutrient retention and nutrient-use efficiency in Phragmites australis stands after wastewater applications. Wetlands 22: 712-721.

Mijangos-Carro M, Izurieta-Dávila J, Gómez-Balandra A, Hernández López R, Huerto Delgadillo R, Sánchez Chávez J, Bravo Inclán L, 2008. Importance of diffuse pollution control in the Pátzcuaro Lake Basin in Mexico. Water Sci. Technol. 58:2179-2186.

Millennium Ecosystem Assessment, 2005. Ecosystems and human well-being: wetlands and water. Synthesis. World Resources Institute, Island Press, Washington: $68 \mathrm{pp}$.

Mitsch WJ, 1992. Landscape design and the role of created, restored, and natural riparian wetlands in controlling nonpoint source pollution. Ecol. Eng. 1:27-47.

Mitsch WJ, Cronk JK, Wu X, Narin RW, Hey DL, 1995. Phosphorus retention in constructed freshwater riparian marshes. Ecol. Appl. 5:830-845.

Morzaria-Luna HN, Castillo-Lopez A, Danemann GD, TurkBoyer P, 2014. Conservation strategies for coastal wetlands in the Gulf of California, Mexico. Wetlands Ecol. Manage. 22: $267-288$.

Murphy J, Riley JP, 1962. A modified single solution method for the determination of phosphate in natural waters. Anal. Chim. Acta 27:31-36.

Neiff JJ, 2001. [Humedales de la Argentina: sinopsis, problemas y perspectivas futuras, p. 83-112]. In: A.F. Cirelli (ed.), [El Agua en Iberoamérica. Funciones de los humedales, calidad de vida y agua segura].[Book in Spanish]. CYTED.

Ockenden MC, Deasy C, Quinton JN, Favaretto N, Stoate C, 2012. The effectiveness of field wetlands in retaining pollutants from agricultural runoff: case studies from the UK, $p$. 244-249. In: K. McCracken (ed.), Valuing Ecosystems: policy, economic and management interactions. Scottish Agricultural College \& Scottish Environment Protection Agency.

Pinay G, Gumiero B, Tabacchi E, Jiménez O, Tabacchi-Planty AM, Hefting MM, Buró TP, Black VA, Nilsson C, Iordache V, Bureau F, Vought L, Petts GE, Décamps H, 2007. Patterns of denitrification rates in European alluvial soils under various hydrological regimes. Freshwater Biol. 52:252-266.

Raisin GW, Mitchell DS, 1995. The use of wetlands for the control of non-point source pollution. Water Sci. Technol. 32:177-186.

Reddy KR, Patrick WH, 1984. Nitrogen transformations and loss in flooded soils and sediments. Crit. Rev. Environ. Control 13:273-309.

Reddy KR, DeLaune R, Craft CB, 2010. Nutrients in wetlands: implications to water quality under changing climatic conditions. Final Report submitted to U.S. Environmental Protection Agency. EPA Contract No. EP-C-09-001. Available from: http://www.ces.fau.edu/climate_change/evergladesrecommendations-2014/pdfs/session-e-resource-3.pdf

Richardson CJ, 1985. Mechanisms controlling phosphorus retention capacity in freshwater wetlands. Science 228:14241427.

Rojas ZA, 2002. [Aportes al proyecto Pátzcuaro: estudios, propuestas y avances para la restauración de la cuenca del lago de Pátzcuaro].[Book in Spanish]. Morevallado Editores, Morelia: $158 \mathrm{pp}$.

Ruiz JM, 2003. [Utilización del balance de cloruros en la zona no saturada en la estimación de la recarga natural a un acuífero 
detrítico, p. 403-408]. In: J. Álvarez-Benedí and P. Marinero (eds.), [Actas de las VI Jornadas sobre Investigación de la Zona no Saturada del Suelo - ZNS'03].[In Spanish]. Instituto Tecnológico Agrario de Castilla y León (I.T.A.).

Sabater S, Butturini A, Clément JC, Burt T, Dowrick D, Hefting M, Maître V, Pinay G, Postolache C, Rzepecki M, Sabater F, 2003. Nitrogen removal by riparian buffers along a European climatic gradient: patterns and factors of variation. Ecosystems 6:20-30.

Sánchez-Chávez J, Bravo-Inclán L, Tomasini-Ortiz C, BernalBrooks F, 2011. [Calidad del agua del lago de Pátzcuaro, p. 29-48]. In: D.R. Huerto, V.S. Vargas and P.C. Ortiz (eds.), [Estudio Ecosistémico del lago de Pátzcuaro].[Book in Spanish]. Instituto Mexicano de Tecnología del Agua, Universidad Autónoma del Estado de Morelos, Universidad Michoacana de San Nicolás de Hidalgo.

Schade JD, Marti E, Welter JR, Fisher SG, Grimm NB, 2002. Sources of nitrogen to the riparian zone of a desert stream: implications for riparian vegetation and nitrogen retention. Ecosystems 5:68-79.

SEPLADE (Secretaría de Planeación y Desarrollo del Estado de Michoacán), 2000. [Programa Hidráulico 2000-2020 del Estado de Michoacán].[In Spanish]. ANEXO calidad de agua superficial.

Simmons RC, Gold AJ, Groffman PM, 1992. Nitrate dynamics in riparian forest: groundwater studies. J. Environ. Qual. 21:659-665.

Smith VH, 2003. Eutrophication of freshwater and coastal marine ecosystems. A global problem. Environ. Sci. Pollut. R. 10:126-139.

Strickland JDH, Parsons TR, 1972. A practical handbook of seawater analysis. Bulletin 167. Fisheries research board of Canada, Ottawa: 310 pp.
Treviño GEJ, Muñoz RCA, Carvazos CC, Barajas CJ, 2002. [Evaluación del flujo hídrico superficial en la Sierra de San Carlos, Tamaulipas].[Article in Spanish]. Ciencia UANL 5:525-530.

Trudell MR, Gillham RW, Cherry JA, 1986. An in-situ study of the occurrence and rate of denitrification in a shallow unconfined sand aquifer. J. Hydrol. 83:251-268.

Vargas TM, Tiscareño LM, Heilmany P, Oropeza MJL, 2000. [Sistema de manejo agrícola bajo decisiones multiobjetivas en la cuenca del lago de Pátzcuaro].[Article in Spanish]. Agric. Tecn. Mex. 26:139-149.

Vellidis G, Lowrance R, Gay P, Hubbard RK, 2003. Nutrient transport in a restored riparian wetland. J. Environ. Qual. 32:711-726.

Viera-Briones A, López-Santos A, González-Barrios JL, Trucios-Caciano R, 2012. [Caracterización de la cuenca ALIP con la ayuda de un sistema de información geográfica].[Article in Spanish]. Revista Chapingo Serie Zonas Áridas 11:23-34.

Vitousek PM, Howarth RW, Likens GE, Matson PA, Schindler D, Schlesinger WH, Tilman GD, 1997. Human alteration of the global nitrogen cycle: causes and consequences. Ecol. Appl. 7:737-750.

Vymazal J, 2007. Removal of nutrients in various types of constructed wetlands. Sci. Total Environ. 380:48-65.

Wetzel RG, 2001. Limnology, lake and river ecosystems. Academic Press, San Diego: 1006 pp.

Woltemade CJ, 2000. Ability of restored wetlands to reduce nitrogen and phosphorus concentrations in agricultural drainage water. J. Soil Water Conserv. 55:303-309.

Zak D, McInnes RJ, Gelbrecht J, 2011. Preface: restoration, biogeochemistry and ecological services of wetlands. Hydrobiologia 674:1-4. 